UDK 631.963:632.51

Nučni rad-Scientific paper

\title{
Analysis of the weed flora of the anthropogenically modified shorelines of the Danube-Tisa-Danube canal system
}

\author{
Anđelković Ana, Marisavljević Dragana, Pavlović Danijela \\ Institute for Plant Protection and Environment, Teodora Drajzera 9, 11040 Belgrade, Serbia \\ e-mail: ana.andjelkovic21@gmail.com
}

\begin{abstract}
SUMMARY
Agricultural intensification has, over the last two centuries, led to an overall reduction in biodiversity and ecosystem funcionality of riparian areas in Europe. Knowing that such frequent and far-reaching anthropogenic disturbances affect native plant diversity and given the geographical position of the Danube-Tisa-Danube (DTD) canal system in the Vojvodina Province, as the main agricultural area of Serbia, the aim of this research was to analyze the weed flora along the shorelines of the DTD canals. Field studies were conducted in 2015 and 2016 at 33 field sites distributed along the six main canals of the DTD system. A total of 188 plant taxa, belonging to 137 genera and 48 families were recorded. The biological spectrum of the weed flora was shown to be of a hemicryptophyto-therophyte character, with $37 \%$ of hemicryptophytes and $30 \%$ of therophytes recorded. Phytogeographical analysis has highlighted a clear dominance of Eurasian species (44\%), while high proportions of adventive and cosmopolitan species recorded are consistent with strong anthropogenic pressures characteristic of the shorelines of the DTD canal system. Among the adventive areal type, 19 species which are considered as invasive for the territory of Serbia have also been documented.
\end{abstract}

Keywords: weeds, riparian areas, biological spectrum, areal types, invasive alien plants.

\section{INTRODUCTION}

Riparian areas are transional zones between the terrestrial and aquatic ecosystems. Consequently, they affect the structure and functioning of both aquatic and terrestrial communities (Bruno et al., 2019). In addition to fulfilling a plethora of important ecosystem functions and providing many important reources (see Breton et al., 2014), riparian areas 
are also important ecological corridors, connecting various habitat types and enabling the movement and dispersal of both plant and animal species (Naiman et al., 1993).

Numerous anthropogenic impacts have often led to landscape degradation in riparian zones, resulting in low habitat diversity, and subsequently reduced biodiversity and ecosystem functioning (Brederveld et al., 2011). Estimates show that nearly $80 \%$ of riparian zones have become degraded in Europe and North America over the last two centuries, primarily owing to agricultural intesification (Naiman et al., 1993). Such vast and frequent disruptions of these complex ecosystems have also led to them being highly susceptible to plant invasions by alien species (Planty-Tabacchi et al., 1996), affecting the native plant diversity and many ecosystem functions native riparian vegetation generally provides (Vilà and Hulme, 2017).

Danube-Tisa-Danube (DTD) canal system is an important corridor interconnecting major river reaches in the Vojvodina Province and spanning the entire northern low-lying territory (the Pannonian plain) of Serbia. Therefore, bearing in mind its importance and geographical position in the heart of the Vojvodina Province, as the main agricultural area of Serbia, our aim was to evaluate the diversity and structure of the weed flora forming the transitional riparian plant communities along the shorelines of this complex and anthropogenically defined irrigation system.

\section{MATERIAL AND METHODS}

Study area. The Danube-Tisa-Danube canal system is a branched out system connecting the inland waters of the Backka and Banat regions in the northern Vojvodina Province of Serbia. It is the largest hydrotechnical complex in the non-Russian part of Europe (Gavrilović and Dukić, 2014). It is an important buffer for the entire area it covers, as its construction has solved the issues of irrigation and flood protection in the territories of the Bačka and Banat regions (Gavrilović and Dukić, 2014; Grabić et al., 2016).

Field research. Field research was carried out during the vegetation seasons of 2015 and 2016, along the six main canal sections of the Danube-Tisa-Danube canal system: I) Banatska Palanka - Novi Bečej, II) Bečej - Bogojevo, III) Karavukovo - Bački Petrovac, IV) Novi Sad Savino Selo, V) Veliki Bački kanal, VI) Kikindski kanal. Floristic analysis was done at a total of 165 plots set up at 33 field sites distributed along the six canal sections (Figure 1). Longitudinal transects consisting of five $20 \mathrm{~m}^{2}$ plots lined along the transect (Aguiar et al., 2001) and set up parallel to the canal flow, in the transitional zone between the water edge and the top of the embankment, were analysed at each field site (Anđelković, 2019). Identification of the plant material was done in the field or in the Laboratory of Weed Research at the Institute for Plant Protection and Environment, following the standard literature (Josifović, 1970-1977; Javorka and Csapody, 1975). Nomenclature of the documented taxa follows the Euro-Med PlantBase (Euro+Med, 2006-2020). 


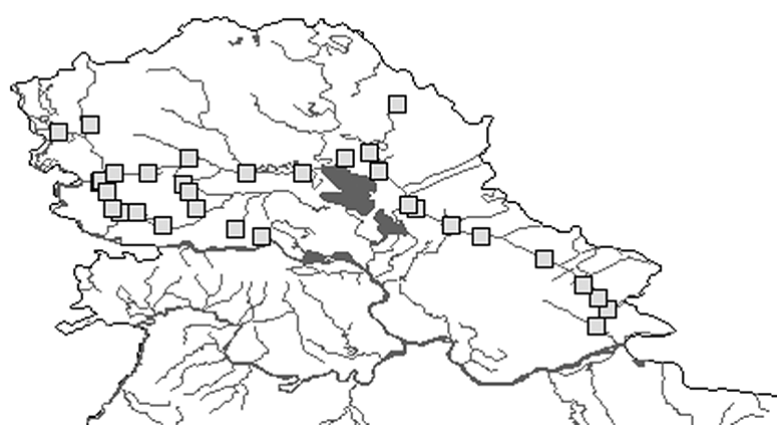

Figure 1. Geographical distribution of the analysed field sites along the Danube-Tisa-Danube canal network in the territory of the Vojvodina Province

Slika 1. Prostorna distribucija analiziranih lokaliteta duž mreže kanala hidrosistema Dunav-Tisa-Dunav na području AP Vojvodine

Data analysis. Field sites were georeferenced using a Garmin GPS eTrex10 device, and the map of distribution was made using Diva-GIS 7.5 softvare (Hijmans et al., 2012). Life forms were determined following the Raunkier system (Ellenberg and Mueller-Dumbois, 1974) and Gajić (1984), in line with the adaptation for the territory of Serbia (Stevanović, 1992a). Chorological analysis was done following Gajić (1980) and Meusel et al. (1965, 1978), applying the areal type delineations for the territory of Serbia defined by Stevanović (1992b).

\section{RESULTS AND DISCUSSION}

Taxonomic analysis. Based on the field studies conducted along the DTD canal network, a total of 188 taxa, belonging to 137 genera and 48 families were recorded (Table 1). Just one species - Equisetum arvense, belonging to the phylum Equisetophyta, was recorded, while the remaining taxa $(99.47 \%)$ belong to the phylum Magnoliophyta. Representatives of the genera Bromus, Carex, Digitaria and Juncus were only identified to the genus level, while all other taxa were determined to the species and subspecies levels. Even though the observed floristic diversity seems low, when compared to some other floristic studies (e.g. Tmušić et al., 2019) of the same geographic area and similar habitat type, this disparity can be ascribed to the level of disturbance and changes in land use of the studied sites, which have led to a reduction in biodiversity (Brederveld et al., 2011). Agricultural intensification has resulted in a loss of species diversity and changes in species composition, favoring ruderal and nitrophilous plant species (see Bourgeois et al., 2016), leading to diversity levels more characteristic of agroecosystems (e.g. Nikolić et al., 2013; Mehmeti et al., 2019; Anđelković et al., in press). A similar loss, primarily exhibited as a reduction in the number of steppe species, as a result of anthropogenic influences (agricultural biotopes) and consequent ruderalization of the natural flora, has also been observed by Jakovljević et al. (2008) for the area of Višnjička kosa. 
Table 1. List of the taxa recorded on the anthropogenically modified shorelines of the Danube-Tisa-Danube canal system

Tabela 1. Lista taksona registrovanih na antropogeno modifikovanim obalama sistema kanala Dunav-Tisa-Dunav

\begin{tabular}{|c|c|}
\hline Classis: Equisetopsida & Lepidium draba $\mathrm{L}$. \\
\hline Family: Equisetaceae & Noccaea perfoliata (L.) Al-Shehbaz \\
\hline Equisetum arvense $\mathrm{L}$. & Myagrum perfoliatum $\mathrm{L}$. \\
\hline Classis: Pinopsida & Sinapis alba $\mathrm{L}$. \\
\hline Family: Pinaceae & Sinapis arvensis $\mathrm{L}$. \\
\hline Pinus nigra J. F. Arnold & Sisymbrium officinale (L.) Scop. \\
\hline Classis: Magnoliopsida & Rorippa sylvestris (L.) Besser \\
\hline Family: Aristolochiaceae & Thlaspi arvense $\mathrm{L}$. \\
\hline Aristolochia clematitis L. & Family: Tiliaceae \\
\hline Family: Ranunculaceae & Tilia cordata Mill. \\
\hline Clematis vitalba $\mathrm{L}$. & Family: Malvaceae \\
\hline Ranunculus repens $\mathrm{L}$. & Abutilon theophrasti Medik. \\
\hline Ranunculus acris L. & Althaea officinalis $\mathrm{L}$. \\
\hline Family: Papaveraceae & Malva pusilla Sm. \\
\hline Papaver rhoeas $\mathrm{L}$. & Malva sylvestris $\mathrm{L}$. \\
\hline Family: Juglandaceae & Family: Cannabaceae \\
\hline Juglans nigra $\mathrm{L}$. & Humulus lupulus L. \\
\hline Juglans regia $\mathrm{L}$. & Family: Urticaceae \\
\hline Family: Portulacaceae & Urtica dioica $\mathrm{L}$. \\
\hline Portulaca oleracea aggr. & Family: Euphorbiaceae \\
\hline Family: Caryophyllaceae & Euphorbia esula L. \\
\hline Silene latifolia Poir. & Euphorbia helioscopia L. \\
\hline Silene vulgaris (Moench) Garcke & Euphorbia palustris L. \\
\hline Stellaria media (L.) Cirillo & Family: Vitaceae \\
\hline Family: Amaranthaceae & Vitis vinifera $\mathrm{L}$. \\
\hline Amaranthus retroflexus $\mathrm{L}$. & Family: Rosaceae \\
\hline Family: Chenopodiaceae & Crataegus monogyna Jacq. \\
\hline Atriplex patula $\mathrm{L}$. & Potentilla argentea $\mathrm{L}$. \\
\hline Chenopodium album $\mathrm{L}$. & Potentilla reptans $\mathrm{L}$. \\
\hline Chenopodiastrum hybridum (L.) S. Fuentes \& al. & Prunus cerasifera Ehrh. \\
\hline Lipandra polysperma (L.) S. Fuentes \& al. & Prunus mahaleb L. \\
\hline Family: Polygonaceae & Pyrus communis subsp. pyraster (L.) Ehrh. \\
\hline Fallopia convolvulus (L.) Á. Löve & Rosa canina $\mathrm{L}$ \\
\hline Persicaria lapathifolia (L.) Delarbre & Rubus caesius L. \\
\hline Persicaria maculosa Gray & Sorbus austriaca (Beck) Prain \& al. \\
\hline Polygonum aviculare aggr. & Family: Lytheraceae \\
\hline Rumex acetosa L. & Lythrum salicaria $\mathrm{L}$. \\
\hline Rumex crispus L. & Family: Fabaceae \\
\hline Rumex hydrolapathum Huds. & Amorpha fruticosa $\mathrm{L}$. \\
\hline Rumex obtusifolius L. & Astragalus glycyphyllos $\mathrm{L}$. \\
\hline Rumex palustris $\mathrm{Sm}$. & Astragalus onobrychis $\mathrm{L}$. \\
\hline Family: Hypericaceae & Glycyrrhiza echinate L. \\
\hline Hypericum perforatum $\mathrm{L}$. & Lathyrus aphaca L. \\
\hline Family: Salicaceae & Lotus corniculatus $\mathrm{L}$. \\
\hline Populus alba L. & Medicago lupulina $\mathrm{L}$. \\
\hline Populus nigra $\mathrm{L}$. & Medicago sativa $\mathrm{L}$. \\
\hline Salix alba L. & Melilotus officinalis (L.) Pall. \\
\hline Salix euxina I. V. Belyaeva & Robinia pseudoacacia L. \\
\hline Salix triandra $\mathrm{L}$. & Securigera varia (L.) Lassen \\
\hline Family: Cucurbitaceae & Trifolium pratense $\mathrm{L}$. \\
\hline Echinocystis lobata (Michx.) Torr. \& A. Gray & Trifolium repens $\mathrm{L}$. \\
\hline Family: Brassicaceae & Vicia grandiflora Scop. \\
\hline Hirschfeldia incana (L.) Lagr.-Foss. & Vicia cracca L. \\
\hline Brassica napus L. & Vicia lutea L. \\
\hline Capsella bursa-pastoris (L.) Medik. & Family: Geraniaceae \\
\hline
\end{tabular}


Erodium cicutarium (L.) L'Herit.

Geranium molle L.

Family: Cornaceae

Cornus mas L.

Cornus sanguinea $\mathrm{L}$.

Family: Sambucaceae

Sambucus ebulus L.

Family: Dipsacaceae

Dipsacus fullonum $\mathrm{L}$.

Dipsacus laciniatus L.

Scabiosa ochroleuca L.

Family: Apiaceae

Anthriscus cerefolium (L.) Hoffm.

Aegopodium podagraria L.

Conium maculatum L.

Daucus carota L.

Eryngium campestre L.

Pastinaca sativa L.

Family: Asteraceae

Achillea millefolium L.

Ambrosia artemisiifolia $\mathrm{L}$.

Arctium lappa L.

Artemisia vulgaris $\mathrm{L}$.

Bellis perennis L.

Bidens tripartitus $\mathrm{L}$.

Carduus acanthoides $\mathrm{L}$.

Centaurea jacea $\mathrm{L}$.

Centaurea micrantha Hoffm. \& Link

Cichorium intybus $\mathrm{L}$.

Cirsium arvense (L.) Scop.

Cirsium vulgare (Savi) Ten.

Crepis foetida $\mathrm{L}$.

Erigeron annuus (L.) Desf.

Erigeron canadensis L.

Inula britannica $\mathrm{L}$.

Lactuca serriola L.

Matricaria chamomilla L.

Picris hieracioides L.

Senecio leucanthemifolius subsp. vernalis (Waldst. \& Kit.)

Greuter

Senecio vulgaris L.

Solidago canadensis L.

Solidago gigantea Aiton

Sonchus asper (L.) Hill

Sonchus oleraceus L.

Symphyotrichum spp.

Tanacetum vulgare $\mathrm{L}$.

Taraxacum officinale $\mathrm{L}$.

Xanthium spinosum $\mathrm{L}$.

Xanthium orientale subsp. italicum (Moretti) Greuter

Family: Rubiaceae

Galium aparine L.

Galium mollugo L.

Galium palustre L.

Galium verum $\mathrm{L}$.

Family: Asclepiadaceae

Asclepias syriaca $\mathrm{L}$.

Family: Solanaceae

Datura stramonium L.
Solanum dulcamara L.

Solanum nigrum L.

Family: Convolvulaceae

Calystegia sepium (L.) L.Br.

Convolvulus arvensis $\mathrm{L}$.

Family: Oleaceae

Fraxinus pennsylvanica Marhsal

Family: Scrophulariaceae

Linaria vulgaris Mill.

Verbascum nigrum $\mathrm{L}$.

Verbascum lychnitis L.

Family: Plantaginaceae

Plantago altissima $\mathrm{L}$.

Plantago lanceolata $\mathrm{L}$.

Plantago major L.

Plantago media L.

Family: Verbenaceae

Verbena officinalis L.

Family: Lamiaceae

Glechoma hederacea L.

Lamium amplexicaule $\mathrm{L}$.

Lamium maculatum L.

Lamium purpureum L.

Lycopus europaeus L.

Mentha aquatica $\mathrm{L}$.

Mentha arvensis $\mathrm{L}$.

Mentha longifolia (L.) L.

Mentha pulegium L.

Salvia nemorosa L.

Stachys palustris L.

Thymus serpyllum $\mathrm{L}$.

Family: Betulaceae

Betula pendula Roth

Family: Corylaceae

Corylus avellana $\mathrm{L}$.

Family: Moraceae

Broussonetia papyrifera (L.) Vent.

Family: Simaroubaceae

Ailanthus altissima (Mill.) Swingle

Family: Rhamnaceae

Rhamnus cathartica L.

Class: Liliopsida

Family: Alismataceae

Alisma plantago-aquatica L.

Family: Juncaceae

Juncus sp.

Family: Cyperaceae

Carex sp.

Family: Poaceae

Alopecurus pratensis $\mathrm{L}$.

Arrhenatherum elatius (L.) J. Presl \& C. Presl

Bromus sp.

Calamagrostis epigeios (L.) Roth

Cynodon dactylon (L.) Pers.

Dactylis glomerata L.

Digitaria sp.

Echinochloa crus-galli (L.) P. Beauv.

Elytrigia repens (L.) Nevski

Hordeum murinum L. 
Lolium sp.

Paspalum distichum $\mathrm{L}$.

Phragmites australis (Cav.) Steud.

Ochlopoa annua (L.) H. Scholz

Poa pratensis L.

Poa palustris L.

\author{
Poa trivialis L. \\ Setaria pumila (Poir.) Roem. \& Schult. \\ Setaria verticillata (L.) P. Beauv. \\ Setaria viridis (L.) P. Beauv. \\ Sorghum halepense (L.) Pers. \\ Triticum aestivum $\mathrm{L}$.
}

Based on the number of recorded taxa, the most abundant families were Asteraceae (31 taxa), Poaceae (21), Fabaceae (16), Lamiaceae (13), and Brassicaceae (11). The recorded dominance of the Asteraceae family is in line with the overall floristic spectrum of Serbia (Stevanović et al., 1995) and the Balkan region (Turill, 1929). Additionally, such an abundance of the Asteraceae family can be further explained by the fact that a significant number of non-native taxa recorded in this study $(34.78 \%$, Table 2$)$ belong precisely to the Asteraceae family. Similar conclusions pertaining to the dominance of plants of the Asteraceae family in the riparian vegetation along the Danube river were also drawn by Tmušić et al. (2019).

Poaceae family are the second most abundant group of taxa recorded in this study, as is also the case for the taxonomic spectrum of Serbia (Stevanović et al., 1995). This result can be further supported by taking into consideration the dominant habitat types (i.e. grasslands and meadows) and dominant vegetation found in the study area (data not shown). The region of steppes in Serbia is represented primarily by the Pannonian province (Jakovljević et al., 2020), and grasses (Poaceae) and other graminoid plant species are known to be characteristic of this zonal vegetation type (Wesche et al., 2016, in Jakovljević et al., 2020). Moreover, as is the case with the riparian zone of the Danube river, the embankments developed along the canal network are very suitable for the growth of grass species belonging to this family (Tmušić et al., 2019). Similar explanations relating to the geographical position of the study area and the dominant habitat types observed (data not shown) can be extrapolated for the relatively lower ratio of the Fabaceae family (fourth most represented family, Table 1), when compared to the flora of Serbia (Stevanović et al., 1995) and the Balkan peninsula (Turill, 1929).

Biological spectrum analysis. The species recorded along the canal network shoreline were grouped into seven basic life form types, including two transitional life forms (Figure 2 ). The analysis of the life-form spectrum of the weed flora has shown a dominance of hemicryptophytes (37\%), followed by therophytes (30\%), as the second most abundant life form group. Such a dominance of hemicryptophytes is fully in line with the expected biological spectrum for the temperate region of Europe (Raunkier, 1934), the overall biological spectrum of Serbia (Diklić, 1984) and a number of floristic studies conducted over the last decade (Jakovljević and Jovanović, 2005; Popović and Obratov-Petković, 2006; Jušković et al., 2010; Jotić et al., 2011; Brković, 2015; Gavrilović, 2016; Sarajlić et al., 2019; Tmušić et al., 2019; Jakovljević et al., 2020).

The fact that therophytes represent the second most dominant group can be further explained by the general floristic tendencies in Serbia (Diklić, 1984) and the Balkan peninsula (Turill, 1929), but also by their life strategies, which enable therophytes to be the most abundant group of agricultural weeds, as was also shown by Nikolić et al. (2013) and Mehmeti et al. (2019). 
Habitats under strong anthropogenic influences and frequent disturbances are characterized by high proportions of R-selected species, i.e. therophytes (Šilc et al., 2012). Such species characterized by a short life cycle and production of numerous small and light seeds are effectively preadapted for colonizing the often-disturbed riparian habitats (Brederveld et al., 2011), as are the anthropogenically conditioned shorelines of the DTD canal network. Moreover, bearing in mind the position of the DTD canal system within the Vojvodina Province, as the main agricultural area of Serbia, this can further explain the high number of therophyte species. A similarly high proportion of therophytes was also evident in the urban ruderal flora (Jakovljević and Jovanović, 2005; Jakovljević et al., 2008; Gavrilović, 2016), owing to the same environmental factors.

Phanerophytes were the third most represented group, with $14 \%$, which contrasts with their overall contribution to the Serbian flora (7.4\%, Diklić, 1984). Nevertheless, our results go fully in line with the more recent studies conducted by Jakovljević and Jovanović (12\% share of phaneophytes, 2005), Gavrilović (10.84\%, 2016), Tmušić et al. (11\%, 2019), and Sarajlić et al. (17\%, 2019). Furthermore, considering that $23 \%$ of the recorded phanerophytes are alien species, this is an additional factor affecting the higher representation of phanerophytes within the study area, when compared to the overall flora of Serbia.

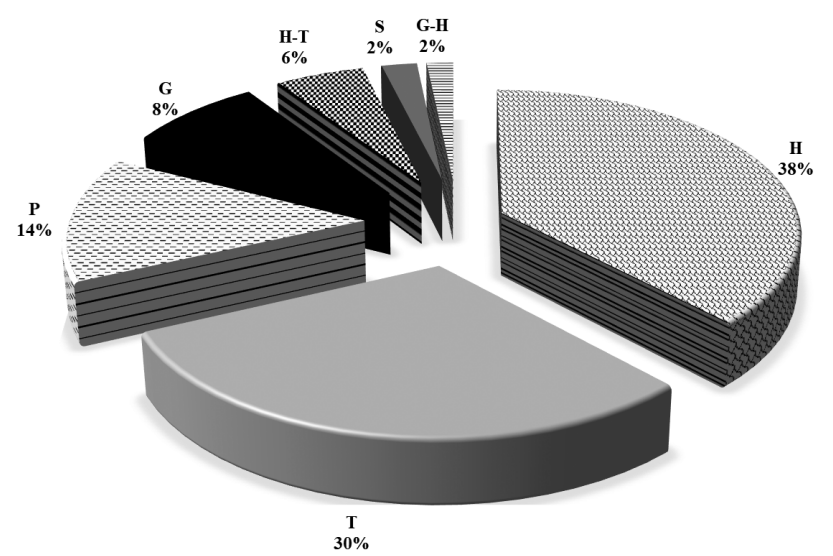

Figure 2. Biological spectrum of the weed flora on the shorelines of the Danube-Tisa-Danube canal system (T Therophyte, H - Hemicryptophyte, P - Phanerophyte, G - Geophyte, H-T - Hemicryptophyto-Therophyte, G-H - Geophyto-Hemicryptophyte, S - Scandetophyte)

Slika 2. Biološki spektar korovske flore na obalama sistema kanala Dunav-Tisa-Dunav ( $\mathrm{T}$ - terofite, H hemikriptofite, P - fanerofite, G - geofite, H-T - hemikripto-terofite, G-H - geofito-hemikriptofite, S - skandetofite)

Geophytes made up 8\% of the recorded species and knowing that geophytes are welladapted to open grasslands (Brković, 2015), extreme environmental conditions and frequent disturbances (Duchoslav, 2009), their presence is not unexpected in the study area. Majority of geophytes recorded (53.33\%) are rhizomatous geophytes, which is characteristic for unstable habitats, under strong anthropogenic pressures (Jakovljević and Jovanović, 2005). The 
transitional life form groups, therophyto-hemicryptophytes and geophyto-hemicryptophytes were represented by ten and three species, respectively.

Analysis of the phenology of the recorded taxa (Figure 3) shows that the majority (56\%) are the summer flowering plants. The spring-summer flowering plants make up $18 \%$ of the recorded taxa, followed by summer-autumn and spring plants, with $8 \%$ each. Similar prevalence of summer flowering plants was also observed for the ruderal flora of the cities of Smederevska Palanka (Jakovljević and Jovanović, 2005) and Novi Sad (Gavrilović, 2016) and the vineyard weed flora of the Vršac vineyards (Anđelković et al., in press), all experiencing strong anthropogenic disturbances.

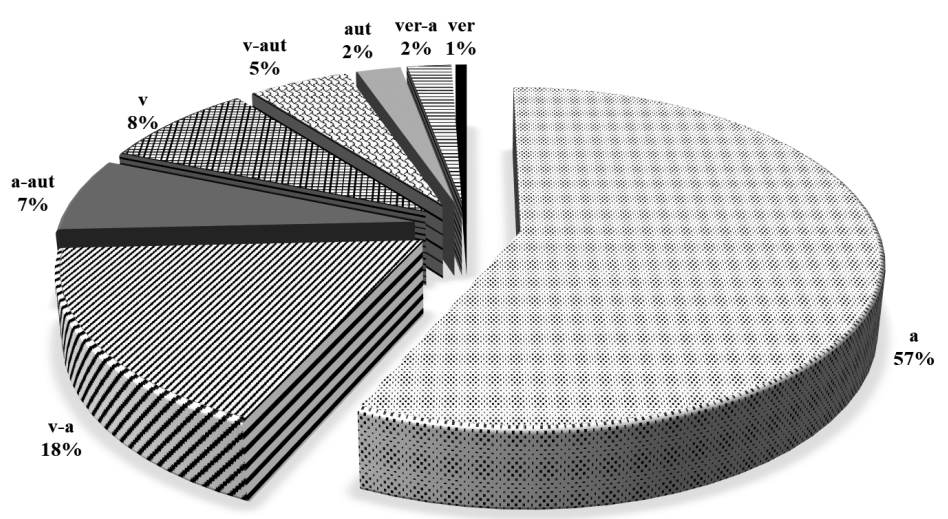

Figure 3. Phenology analysis of the weed flora on the shorelines of the Danube-Tisa-Danube canal system (a summer (lat. aestivus), $\mathrm{v}$ - spring (lat. vernus, vernalis), aut - autumn (lat. autumnalis))

Slika 3. Analiza fenologije korovske flore na obalama kanala Dunav-Tisa-Dunav (a - letnje cvetajuće (lat. aestivus), $\mathrm{v}$ - prolećno cvetajuće (lat. vernus, vernalis), aut - jesenje cvetajuće (lat. autumnalis))

Phytogeographical analysis. Phytogeographical analysis of the weed flora of the DanubeTisa-Danube canal system shoreline shows a strong dominance of Eurasian species (44\%, Figure 4). According to Gavrilović (2016), such results are expected for the floristic studies conducted in our region, given that our study area belongs to the biome of temperate grasslands (Willner et al., 2020). This has also been confirmed by a number of different floristic studies conducted in Serbia, also portraying a strong prevalence of the species of Eurasian origin (Jotić et al., 2011; Brković, 2015; Gavrilović, 2016; Tmušić et al., 2019). The second most abundant group were Central-European species with 25 representatives (14\%, Figure 4).

Presence of 19 Pontic-South Siberian species, which can be considered steppe-like sensu lato, was to be expected given the geographic position (i.e. distribution of the Pontic-South Siberian biogeographical region) and prevalent habitat types characteristic for the study area, whereby it has been shown by Jakovljević et al. (2020) that Pontic-European taxa comprise almost 50\% of the overall steppe flora in Serbia. Additionally, significant anthropogenic activities (e.g. forest clearances) and climate change have also favored the presence and abundance of these xerothermic species, according to Ranđelović et al. (2007). 
High proportion of cosmopolitan (10\%) and adventive (12\%) species is in line with anthropogenic disturbances which are frequent in the study area, thus favoring the survival of easily adaptable species, with a wide ecological valence. Del Tredici (2010) and Šilc et al. (2012) have highlighted the propensity of such intensely anthropogenically-disturbed habitats for harboring significant proportions of alien species. Similar observations regarding cosmopolitan and alien species have also been made by Tmušić et al. (2019) for the riparian flora of the Danube's shoreline, the urban and suburban floras of the cities of Novi Sad (Gavrilović, 2016) and Smederevska Palanka (Jakovljević and Jovanović, 2005) and the invaded stands of common milkweed (ass. Asclepiadetum syriacae) in Serbia (Popov et al., 2016). Prevalence of Eurasian, cosmopolitan and adventive species are also characteristic for various types of weedy-ruderal communities, according to Kojić et al. (1998), thus further supporting the observed ratios (Figure 4).

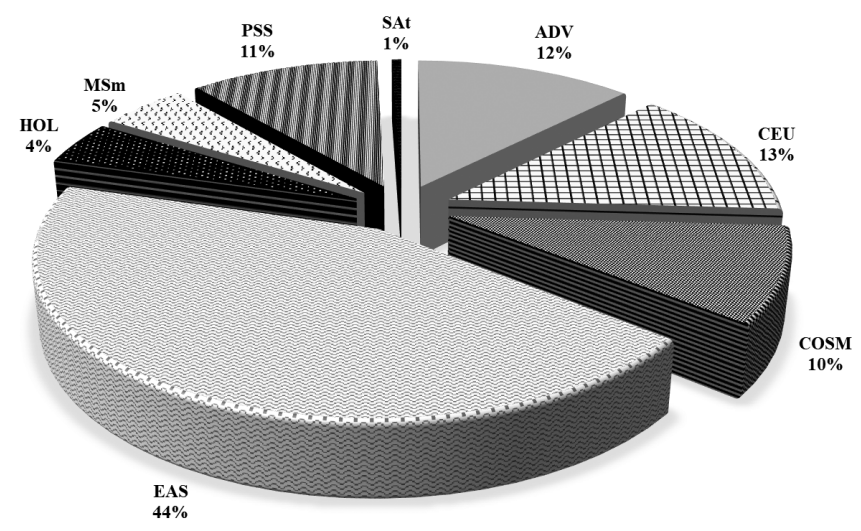

Figure 4. Horological spectrum of the weed flora on the shorelines of the Danube-Tisa-Danube canal system (EAS - Eurasian, CEU - Central-European, ADV - Adventive, COSM - Cosmopolitan, PSS - Pontic-South Siberian, MSm - Mediterranean-Sub Mediterranean, HOL - Holarctic, SAt - Sub-Atlantic)

Slika 4. Horološki spektar korovske flore obala kanala sistema Dunav-Tisa-Dunav (EAS - Evroazijski, CEU centralno-evropski, ADV - adventivni, COSM - kosmopolitski, PSS - pontsko-južnosibirski, MSm - mediteranskosubmediteranski, HOL - holarktički, SAt - subatlantski)

Invasive alien plants. Frequent habitat disturbances and high nutrient input are indicative of strongly invaded habitats in the Balkan Peninsula (Šilc et al., 2012). Consequently, the number of invasive alien plants documented along the shorelines of the DTD canal system (Table 2) is unsurprising. Additionally, it has become well-known that anthropogenic pressures, such as channelization, agricultural development, and riparian deforestation all favor the presence and spread of highly competitive, and often invasive, alien species (Bruno et al., 2019). Moreover, Grantham et al. (2013) have shown that certain anthropogenic impacts, such as water use for irrigation purposes, lead to alterations and reductions in the magnitude of flow and seasonal variations of natural flow patterns, which could additionally exacerbate the expansion of invasive alien plants. 
Of the 24 alien (adventive) taxa which have been recorded in the study area (Figure 4), 19 are considered invasive (Table 2) for the territory of Serbia following Lazarević et al. (2012) and the List of invasive species in the Vojvodina Province (IASV, 2011). Majority of the recorded invasive alien plants belongs to the family Asteraceae, which is in line with the overall invasion trends for Europe (Pyšek et al., 2009). Highly invasive taxa are most numerous (63.16\%), which is expected, given their invasive nature, and the results reported for the invasibility of the riparian areas in Serbia overall (Anđelković, 2019).

Regarding their native range, the North American taxa are most numerous (78.95\%, Table 2), followed by species of Asian origin (15.79\%, Table 2). Dominance of North American species is characteristic for the flora of invasive plants in the riparian areas of Europe (Schnitzler et al., 2007; Liendo et al., 2015), and such a prevalence has also been reported for wetlands and riparian areas in Serbia (Stanković, 2018; Anđelković, 2019).

Table 2. Invasive alien species in the weed flora on the shorelines of the Danube-Tisa-Danube canal system Tabela 2. Strane invazivne vrste u korovskoj flori obala kanala sistema Dunav-Tisa-Dunav

\begin{tabular}{|c|c|c|c|}
\hline $\begin{array}{l}\text { Family } \\
\text { Familija }\end{array}$ & $\begin{array}{l}\text { Species } \\
\text { Vrsta }\end{array}$ & $\begin{array}{l}\text { Invasiveness status* } \\
\text { Status invazivnosti }{ }^{*}\end{array}$ & $\begin{array}{l}\text { Origin } \\
\text { Poreklo }\end{array}$ \\
\hline Aceraceae & Acer negundo L. & Highly invasive & North America \\
\hline Amaranthaceae & Amaranthus retroflexus $\mathrm{L}$. & Highly invasive & North America \\
\hline Asclepiadaceae & Asclepias syriaca $\mathrm{L}$. & Highly invasive & North America \\
\hline Asteraceae & Ambrosia artemisiifolia L. & Highly invasive & North America \\
\hline Asteraceae & Erigeron annuus (L.) Pers. & Highly invasive & North America \\
\hline Asteraceae & Erigeron canadensis L. & Highly invasive & North America \\
\hline Asteraceae & Solidago canadensis L. & Sporadically invasive & North America \\
\hline Asteraceae & Solidago gigantea Aiton & Highly invasive & North America \\
\hline Asteraceae & Symphyotrichum spp. & Potentially invasive & North America \\
\hline Asteraceae & Xanthium spinosum $\mathrm{L}$. & Potentially invasive & South America \\
\hline Asteraceae & $\begin{array}{l}\text { Xanthium orientale subsp. italicum (Moretti) } \\
\text { Greuter }\end{array}$ & Sporadically invasive & North America \\
\hline Cucurbitaceae & Echinocystis lobata (Minchx.) Torr. \& A. Gray & Highly invasive & North America \\
\hline Fabaceae & Amorpha fruticosa $\mathrm{L}$. & Highly invasive & North America \\
\hline Fabaceae & Robinia pseudoacacia L. & Highly invasive & North America \\
\hline Malvaceae & Abutilon theophrasti Medik. & ** & Asia \\
\hline Moraceae & Broussonetia papyrifera (L.) Vent. & Potentially invasive & Asia \\
\hline Oleaceae & Fraxinus pennsylvanica Marshall & Sporadically invasive & North America \\
\hline Poaceae & Paspalum distichum $\mathrm{L}$. & Highly invasive & $\begin{array}{l}\text { North, Central America, } \\
\text { Australia, Oceania }\end{array}$ \\
\hline Simaroubaceae & Ailanthus altissima (Mill.) Swingle & Highly invasive & Asia \\
\hline \multicolumn{4}{|c|}{ * following Lazarević et al. (2012) } \\
\hline \multicolumn{4}{|c|}{ ** not classified according to Lazarević et al. (2012), but included in the IASV list of invasive plants (IASV, 2011) } \\
\hline * u skladu sa Laza & ević i sar. (2012) & & \\
\hline
\end{tabular}




\section{CONCLUSION}

Floristic analysis of the weed flora of the anthropogenically modified shorelines of the DTD canal system has pointed to a somewhat reduced plant diversity for this area and habitat type. A total of 188 plant taxa were recorded, with a clear dominance of the Asteraceae and Poaceae families. Analysis of the biological spectrum has shown a clear hemicryptophyto-therophyte character, with a strong presence of phanerophytes. Phytogeographical analysis has shown a prevalence of Eurasian species, with significant proportions of cosmopolitan and adventive (alien) plants. The recorded floristic, life form and phytogeographical spectra are a clear indication of the intense and frequent anthropogenic disturbances strongly affecting the study area, which is further highlighted by the alarming presence of 19 invasive alien plant species.

\section{ACKNOWLEDGEMENT}

This research was conducted under the framework of the Ministry of Education, Science and Technological Development of the Republic of Serbia (Project No. TR31018), and the authors are grateful to the Ministry for its ongoing financial support (Grant No. 451-03-68/2020-14/200010).

\section{LITERATURE}

Aguiar, F. C., Ferreira, M. T., Moreira, I.: Exotic and native vegetation establishment following channelization of a western Iberian river. Regulated Rivers: Research \& Management: An International Journal Devoted to River Research and Management, 17 (4-5), 509-526, 2001.

Anđelković, A.: Akvatični koridori biljnih invazija u Srbiji. Doktorska disertacija, Univerzitet u Novom Sadu, Prirodno-matematički fakultet, Departman za biologiju i ekologiju, 2019.

Anđelković, A., Marisavljević, D., Cvijanović, D., Radulović, S., Pavlović, D.: Biological spectrum of the weed flora of the Vršac vineyards (Serbia). Matica Srpska Journal of Natural Sciences, in press.

Bourgeois, B., Vanasse, A., Rivest, D., Poulin, M.: Establishment success of trees planted in riparian buffer zones along an agricultural intensification gradient. Agriculture, Ecosystems \& Environment, 222, 60-66, 2016.

Brederveld, R. J., Jähnig, S. C., Lorenz, A. W., Brunzel, S., Soons, M. B.: Dispersal as a limiting factor in the colonization of restored mountain streams by plants and macroinvertebrates. Journal of Applied Ecology, 48 (5), 1241-1250, 2011.

Breton, V., Forestier, O., Guindon, O., Evette, A.: Ecological restoration under pressure from invasive animal species: use of Salicaceae cuttings in a riverbank overrun by coypu. River Research and Applications, 30 (8), 1002-1012, 2014.

Brković, D. L.: Vaskularna flora brdsko-planinskog područja severozapadne Srbije i Šumadije-ekološko fitogeografska studija. Doktorska disertacija, Univerzitet u Beogradu, Biološki fakultet, 2015.

Bruno, D., Zapata, V., Guareschi, S., Picazo, F., Dettori, E., Carbonell, J. A., Millán, A., Velasco, J., Robledano, F.: Short-term responses of aquatic and terrestrial biodiversity to riparian restoration measures designed to control the invasive Arundo donax L. Water, 11 (12), 2551, 2019. 
Del Tredici, P.: Spontaneous urban vegetation: reflections of change in a globalized world. Nature and Culture, 5 (3), 299-315, 2010.

Diklić, N.: Životne forme biljnih vrsta i biološki spektar flore SR Srbije. In: Sarić, M. (Ed.): Vegetacija SR Srbije, I: 291-316. - SANU, Posebna izdanja. Beograd, 1984.

Duchoslav, M.: Effects of contrasting habitats on the phenology, seasonal growth, and dry-mass allocation pattern of two bulbous geophytes (Alliaceae) with partly different geographic ranges. Polish Journal of Ecology, 57 (1), 15-32, 2009.

Ellenberg, H., Mueller-Dombois, D.: Aims and methods of vegetation ecology. New York - London: John Willey and Sons, 1974.

Euro+Med: Euro+Med PlantBase - The information resource for Euro-Mediterranean plant diversity. Published on the Internet: [http://ww2.bgbm.org/EuroPlusMed/] (accessed on August 21, 2020), 2006-2020.

Gajić, M.: Pregled vrsta flore SR Srbije sa biljno-geografskim oznakama. Glasnik Šumarskog fakulteta, Beograd, 54 (A), 111-141, 1980.

Gajić, M. R.: Florni elementi SR Srbije. In: Sarić MR (Ed.), Vegetacija SR Srbije. SANU, Beograd, 317-397, 1984.

Gavrilović, M.: Ruderalna flora Novog Sada kao potencijalni prirodni resurs lekovitog bilja. Doktorska disertacija, Univerzitet u Novom Sadu, Prirodno-matematički fakultet, 2016.

Gavrilović, L., Dukić, D.: Reke Srbije. Zavod za udžbenike i nastavna sredstva, 2014.

Grabić, J., Benka, P., Bezdan, A., Josimov-Dunđerski, J., Salvai, A.: Water quality management for preserving fish populations within hydro-system Danube-Tisa-Danube, Serbia. Carpathian Journal of Earth and Environmental Sciences, 11 (1), 235-243, 2016.

Grantham, T. E., Figueroa, R., Prat, N.: Water management in Mediterranean river basins: a comparison of management frameworks, physical impacts, and ecological responses. Hydrobiologia, 719 (1), 451-482, 2013.

Hijmans, R. J., Guarino, L., Mathur, P.: DIVA-GIS. Version 7.5. A geographic information system for the analysis of species distribution data, 2012.

IASV: List of invasive species in AP Vojvodina, Anačkov, G., Bjelić-Čabrilo, O., Karaman, I., Karaman, M., Radenković, S., Radulović, S., Vukov, D., Boža, P. (Eds). Novi Sad (Serbia), 2011 [accessed on September $10,2020]$

Jakovljević, K., Jovanović, S.: Ruderal flora of Smederevska Palanka town: Ecological and phytogeographical characteristics. Acta herbologica, 14 (1), 1-13, 2005.

Jakovljević, K., Lakušić, D., Vukojičić, S., Teofilović, A., Jovanović, S.: Floristic characteristics of Višnjička kosa near Belgrade, Serbia. Archives of Biological Sciences, 60 (4), 703-712, 2008.

Jakovljević, K., Tomović, G., Djordjević, V., Niketić, M., Stevanović, V.: Steppe flora in Serbia-distribution, ecology, centres of diversity and conservation status. Folia Geobotanica, 1-14, 2020.

Javorka, S., Csapody, V.: Icanographie der Flora des Sudostlichen Mitteleuropa. Akademiai Kiado: Budapest, 1975.

Josifović, M. (Ed.): Flora SR Srbije. Vol. I-X. SANU, Beograd, 1970-1986.

Jotić, B., Marković, M., Petrović, B., Fusijanović, I., Pavlović, D., Ranđelović, V.: The vascular flora of the Vučje hill near Pirot city (Eastern Serbia). Biologica Nyssana, 2 (2), 91-106, 2011.

Jušković, M., Ranđelović, V., Zlatković, B., Stevanović, V.: Diversity of the vascular flora of Mt Šljivovički Vis in East Serbia. Phytologia Balcanica, 16 (3), 361-367, 2010.

Kojić, M., Popović, R., Karadžić, B.: Sintaksonomski pregled vegetacije Srbije. Institut za biološka istraživanja „Siniša Stankovićc", Beograd, 1-218, 1998.

Lazarević, P., Stojanović, V., Jelić, I., Perić, R., Krsteski, B., Ajtić, R., Sekulić, N., Branković, S., Sekulić, G., Bjedov, $V$ : : A preliminary list of invasive species in Serbia, with general measures of control and reduction as a basis of future legal acts. Zaštita prirode, 62 (1), 5-31, 2012.

Mehmeti, A., Fetahaj, R., Tiriqi, L., Zogaj, M., Demaj, A.: Weed flora of potato crop in Kosovo. Bulgarian Journal of Agricultural Science, 25 (1), 103-108, 2019.

Meusel, H., Jager, E., Weinert, E.: Vergleinchende Chorologie der Zentraleuropaischen Flora. VEB. Gustav Fischer Verlag, 1, Jena, 1965. 
Meusel, H., Jäger, E., Weinert, E.: Vergleichende Chorologie der Zentraleuropäischen Flora. Gustav Fischer, 2, Jena, 1978.

Naiman, R. J., Decamps, H., Pollock, M.: The role of riparian corridors in maintaining regional biodiversity. Ecological Applications, 3 (2), 209-212, 1993.

Nikolić, Lj., Ilić, O., Džigurski, D., Ljevnaić-Mašić, B.: Analysis of weed flora in conventional and organic potato production. Biologica Nyssana, 4 (1-2), 9-14, 2013.

Planty-Tabacchi, A. M., Tabacchi, E., Naiman, R. J., Deferrari, C., Décamps, H.: Invasibility of species-rich communities in riparian zones. Conservation Biology, 10, 598-607, 1996.

Popov, M. M., Konstantinović, B. B., Nikolić, Lj. M.: Ecological analysis of stands of ass. Asclepiadetum syriacae Lániková in Chytrý 2009 in Bačka region. Zbornik Matice srpske za prirodne nauke, 131, 157-166, 2016.

Popović, I., Obratov-Petković, D.: Analysis of biological spectrum of Divčibare flora. Glasnik Šumarskog fakulteta, 93, 143-154, 2006.

Pyšek, P., Lambdon, P., Arianoutsou, M., Kuhn, I., Pino, J., Winter, M.: Alien Vascular Plants of Europe in Handbook of alien species in Europe. Springer, 2009.

Ranđelović, V., Jušković, M., Šarac, Z.: Horološke i ekološke karakteristike stepskih elemenata flore na području istočne i jugoistočne Srbije. Knjiga sažetaka IX simpozijuma o flori jugoistočne Srbije i okolnih regiona, 01-03/09/2007, 83-99, 2007.

Raunkiaer, C.: The life forms of plants and statistical plant geography. Oxford, Clarendon press, 1934.

Sarajlić, N., Jogan, N., Murtić, S., Ranđelović, V.: Spontaneous flora of the Vraca Memorial Park (Sarajevo, Bosnia and Herzegovina). Biologica Nyssana, 10 (2), 135-142, 2019.

Stanković, V. Đ.: Ekološka studija invazivnih biljnih vrsta u ramsarskim područjima Vojvodine. Doktorska disertacija, Univerzitet u Beogradu, Biološki fakultet, 2018.

Stevanović, V:: Klasifikacija životnih formi flore Srbije. In: Sarić M (Ed.), Flora Srbije, Vol. 1 (2 Ed.), SANU, Beograd, 1992a.

Stevanović, V.: Floristička podela teritorije Srbije sa pregledom viših horiona i odgovarajućih flornih elemenata. In: Sarić, M. (Ed.) Flora Srbije, Vol. 1 (2 Ed.). SANU, Beograd, 1992b.

Stevanović, V., Vasić, V.: Biodiverzitet Jugoslavije sa pregledom vrsta od međunarodnog značaja. Biološki fakultet i Ekolibri, Beograd, 1995.

Šilc, U., Vrbničanin, S., Božić, D., Čarni, A., Stevanović, Z. D.: Alien plant species and factors of invasiveness of anthropogenic vegetation in the Northwestern Balkans- a phytosociological approach. Central European Journal of Biology, 7 (4), 720-730, 2012.

Tmušić, G. M., Rat, M. M., Bokić, B. S., Radak, B. Đ., Radanović, M. M., Anačkov, G. T.: Floristic analysis of the Danube's shoreline from Čerević to Čortanovci. Zbornik Matice srpske za prirodne nauke, 136, 133-153, 2019.

Turill, B. W.: The Plant-Life of the Balkan Peninsula, Oxford, Clarendon, 1929.

Vilà, M., Hulme, P. E.: Impact of Biological Invasions on Ecosystem Services. Springer: Cham, Switzerland, 2017.

Wesche, K., Ambarl, D., Kamp, J., Török, P., Treiber, J., Dengler, J.: The Palaearctic steppe biome: a new synthesis. Biodiversity and Conservation, 25 (12), 2197-2231, 2016.

Willner, W., Roleček, J., Korolyuk, A., Dengler, J., Chytrý, M., Lengyel, A.: Formalized classification of the semidry grasslands of Central and Eastern Europe. Preslia, 91(1), 25-49, 2020.

Žikić, E.: Pedeset godina Hidrosistema Dunav - Tisa - Dunav (1947-1997), Vodoprivreda 1-2, str. 3-7, Beograd, 1998. Analiza korovske flore antropogeno uslovljenih obala kanala hidrosistema Dunav-Tisa-Dunav 


\section{Analiza korovske flore antropogeno uslovljenih obala kanala hidrosistema Dunav-Tisa-Dunav}

\section{REZIME}

Intenziviranje poljoprivredne proizvodnje u protekla dva veka rezultiralo je sveopštim gubitkom biodiverziteta i narušavanjem ekosistemskih funkcija riparijalnih oblasti na području Evrope. Imajući u vidu da učestale antropogene aktivnosti imaju dalekosežni negativni uticaj na diverzitet nativnih biljaka i uzimajući u obzir geografsku poziciju hidrosistema Dunav-TisaDunav (HS DTD) na području AP Vojvodine, kao glavnog poljoprivrednog područja Srbije, cilj ovog istraživanja bio je da se analizira korovska flora duž obala kanala HS DTD. Terenska istraživanja vršena su tokom 2015. i 2016. godine, duž šest glavnih kanala mreže HS DTD na 33 lokaliteta. Ukupno je registrovano prisustvo 188 taksona, iz 137 rodova i 48 familija. Biološki spektar korovske flore je hemikriptofitsko-terofitskog karaktera, sa 37\% udelom hemikriptofita i $30 \%$ terofita. Fitogeografska analiza je ukazala na jasnu dominantnost vrsta evroazijskog areal tipa (44\%), dok je visok udeo adventivnih i kosmopolitskih vrsta u skladu sa snažnim antropogenim pritiskom, karakterističnim za obale kanala HS DTD. U okviru vrsta adventivnog areal tipa, registrovano je 19 vrsta koje se vode kao invazivne na području Srbije.

Ključne reči: korovi, riparijalne oblasti, biološki spektar, areal tipovi, strane invazivne biljke. 